\title{
Yield and phenology of yam as affected by the physiological rest period of seed-rhizomes
}

\author{
Ademar P de Oliveira ${ }^{1}$; Márcio F de Moura²; Edna U Alves ${ }^{1}$; Anarlete U Alves²; Arnaldo Nonato P de \\ Oliveira $^{1}$; Francisco de Assis P Leonardo ${ }^{1}$; Iordam da S Cruz ${ }^{1}$ \\ ${ }^{1}$ UFPB-CCA, C. Postal 2, 58397-000 Areia-PB; ${ }^{2}$ Pós-graduando em Agronomia na UFPB; ademar@cca.ufpb.br
}

\begin{abstract}
The objective of this work was to evaluate the effects of the rest period of seed-rhizomes in the phenology and yield of yam Da Costa (Dioscorea cayennensis). The experiment was carried out in field conditions at the Federal University of Paraíba, in Areia, Brazil, from January to December 2004, in an Ustpsamment soil. A completely randomized block design was used to test three treatments, 60-, 80, and 100-day seed-rhizome rest periods, with seven replications. Plant emergency was evaluated every ten days from 40 to 90 days after planting (DAP), as well as plant height, evaluated up to 80 DAP. The average mass of commercial rhizomes and the yield of commercial and seed-rhizomes were also assessed. At 40, 50, and 60 days after planting, plant emergency was superior for seedrhizomes submitted to 100-day rest periods. At 70 and $80 \mathrm{DAP}$, there were no significant differences. At $90 \mathrm{DAP}$, seed-rhizomes that rested for 60 and 100 days provided around 91 and $83 \%$ of plant emergency, respectively. Concerning plant height, seed-rhizomes that rested 100 days produced the tallest plants. The average mass of commercial rhizomes and the yield of commercial and seed-rhizomes were 1.22 $\mathrm{kg}, 13.1 \mathrm{t} \mathrm{ha}^{-1}$, and $7.7 \mathrm{tha}^{-1}$, respectively, for seed rhizomes submitted to 60 -day rest periods. For 100-day rest period rhizomes, the average mass of commercial rhizomes and the yield of commercial and seedrhizomes, were $0.73 \mathrm{~kg}, 7.7 \mathrm{t} \mathrm{ha}^{-1}$, and $1.7 \mathrm{t} \mathrm{ha}^{-1}$, respectively.
\end{abstract}

Keywords: Dioscorea cayennensis, post-harvest, dormancy, emergency, plant height

\section{RESUMO}

Fenologia e rendimento do inhame em função do período de repouso fisiológico dos rizomas-semente

O trabalho teve como objetivo avaliar o efeito do repouso fisiológico de rizomas-sementes do inhame-da-costa (Dioscorea cayennensis) sobre sua fenologia e rendimento. Foi desenvolvido um experimento a campo, na Universidade Federal da Paraíba, no município de Areia, entre janeiro a dezembro de 2004, em Neossolo Regolítico Psamítico Típico. Os tratamentos foram representados pelos períodos de 60, 80 e 100 dias de repouso fisiológico dos rizomas-sementes. O delineamento experimental empregado foi blocos casualizados, com sete repetições. Foi avaliada a emergência de plantas a partir de 40 dias após o plantio (DAP), em intervalos de dez dias, até 90 dias; a altura de plantas a partir de 40 DAP, também em intervalos de dez dias até 80 DAP, a massa média de rizomas comerciais e as produtividades de rizomas comerciais e de rizomassementes. A emergência de plantas foi maior em rizomas-sementes com 100 dias de repouso fisiológico, 40, 50 e 60 DAP; não ocorreu diferença nas avaliações feitas 70 e 80 DAP e, 90 DAP, rizomassementes com 60 e 100 dias de repouso fisiológico proporcionaram, respectivamente, 91 e $83 \%$ de emergência. Para a característica altura de plantas, rizomas-sementes com 100 dias de repouso produziram as plantas mais altas, até 60 dias após o plantio. A massa média de rizomas e as produtividades de rizomas comerciais e de rizomas-sementes foram de $1,22 \mathrm{~kg}, 13,1 \mathrm{t} \mathrm{ha}^{-1}$ e de 7,7 $\mathrm{t} \mathrm{ha}^{-1}$, respectivamente, para rizomas-semente com 60 dias de repouso fisiológico. Rizomas-sementes com 100 dias de repouso fisiológico apresentaram massa média e produtividade de rizomas comercias e de rizomas-semente de $0,73 \mathrm{~kg}, 7,7 \mathrm{tha}^{-1}$ e $1,7 \mathrm{t} \mathrm{ha}^{-1}$, respectivamente.

Palavras-chave: Dioscorea cayennensis, pós-colheita, dormência, emergência, altura de plantas.

\section{(Recebido para publicação em 21 de maio de 2007; aceito em 14 de abril de 2008)}

Y am (Dioscorea cayennensis Lam.), known in Portuguese as cará-dacosta, holds at the Brazilian Northeast region, especially in the top producing States (Pernambuco and Paraíba), a great socio-economic importance, due to its nourishing rhizomes of high energetic and nutritive values, with a high content of starch (Oliveira et al., 2002). The species is worth of special attention because it is a tropical plant of great potential that can contribute for the solution of the issue of food supply. This is especially relevant in underdeveloped regions, where yam is already widely used as food by all social classes. In the State of Paraíba, producing areas are concentrated in the coastline and in the agro-grazing micro-region of Baixo Paraíba, comprising a planted area of approximately 7.5 thousand hectare year ${ }^{-1}$ and producing around 90 thousand tons (Santos \& Macêdo, 2002).

Yam is vegetatively multiplied through complete seed-rhizomes, which assures a high sprouting percentage and a good plant development; or through parts of the rhizome, named head, half, and end, more frequently used by farmers (Santos, 1998). Nevertheless, the selection of seed-rhizomes for planting is a very important task to the proper exploitation of this plant, since the rhizomes to be produced must match a standard on commercial quality.

Unequal emergence has been leading to considerable losses to producers, due to the death of seedrhizomes, caused by attacks of soilborne insects and pathogens. In addition, adverse climatic conditions may injury the sprouting buds. Under these 
circumstances, it is difficult to control the production of seed-rhizomes, which depends on performing early harvests (top pruning), at seven months. These harvests consist in removing rhizomes from plants by means of a cut at the linking point with the aboveground part, followed by planting to induce the emission of new rhizomes, named mother- or seed-rhizomes. The objectives are to obtain rhizomes to be traded at the off-season period and to induce the production of extra seedrhizomes. Plants kept in the field for two more months can complete their cycles, which results in the production of seedrhizomes (Santos, 1996).

At a high density, it is difficult to control emergence, which may lead to harvest at inadequate maturation stages (Santos, 1998). Finger et al. (2005) define the physiological rest or dormancy as the period during which buds of the rhizomes do not present visible signs of growth, even if stored under ideal sprouting conditions of temperature, light, and air composition. Dormancy is common also in potatoes (Solanum tuberosum L.) and is due to endogenous physiological factors. According to Bisogin et al. (1998), dormancy is a physiological state of the tuber, which begins at tuberization and ends at the emission of at least one sprout. During this period, tuber does not present sprouting capacity even under favourable conditions. Hormonal balance between growth promoters and inhibitors greatly influences this process (Fernandez, 1988). The dormancy period corresponds to the number of days from harvesting to the beginning of tuber sprouting, and is species- and cultivar-specific (Beukema \& Van der Zaag, 1979). Potato tubers are dormant after harvesting. During this period, the metabolic activity is reduced and the internal hormonal balance privileges growth inhibitors. After this period, if environmental conditions of temperature and light favours hormonal balance, first sprouts appear out the apical bud (Souza, 2003).

In yam, the seed-rhizome dormancy period is variable, comprising from a few days to months. However, according to the seed-rhizome storage conditions, some practices can be used to reduce it. Actually, after harvesting, rhizomes usually remain dormant for nearly three months. After that, the process of sprouting begins, both in storage or after planting (Santos, 1996). Sprouting is faster on entire rhizomes, starting at the proximal and progressing to the distal end (Silva, 1971; Araújo, 1982; Santos, 1998).

Our objective was to assess the effects of the physiological rest period of seed-rhizomes on yam phenology and seed-rhizomes yield and production.

\section{MATERIAL AND METHODS}

The experiment was carried out at the Federal University of Paraíba, in Areia, between January and December 2004, using yam da Costa seedrhizomes, recently harvested. The soil of the experimental area was classified as typical Quartz psamment (Embrapa, 1999), with the following chemical characteristics: $\mathrm{pH}\left(\mathrm{H}_{2} \mathrm{O}\right)=7.0 ; \mathrm{P}$ available $=107.54 \mathrm{mg} \mathrm{dm}^{-3} ; \mathrm{K}^{+}$available $=64 \mathrm{mg} \mathrm{dm}^{-3} ; \mathrm{Na}^{+}=0.09 \mathrm{cmol}_{\mathrm{c}} \mathrm{dm}^{-3}$; $\mathrm{H}^{+}+\mathrm{Al}^{+3}=0.91 \mathrm{cmol}_{\mathrm{c}} \mathrm{dm}^{-3} ; \mathrm{Al}^{+3}=0.00$ $\mathrm{cmol}_{\mathrm{c}} \mathrm{dm}^{-3} ; \mathrm{Ca}^{+2}=2.70 \mathrm{cmol}_{\mathrm{c}} \mathrm{dm}^{-3} ; \mathrm{Mg}^{+2}$ $=0.75 \mathrm{cmol}_{\mathrm{c}} \mathrm{dm}^{-3}$; and organic matter $=$ $15.54 \mathrm{~g} \mathrm{dm}^{-3}$.

Rhizomes were submitted to physiological rest periods of 60,80 , and 100 days, stored under shed conditions. The experimental design was randomized complete blocks, with seven replications. After each harvesting period, seed-rhizomes were cut in pieces of approximately $250 \mathrm{~g}$. Afterwards, they were planted on a $1,20 \times 0,60 \mathrm{~m}$ spacing, in furrows previously raised after soil ploughing and harrowing. The experimental unit was composed of 40 plants, out of which 20 were used to evaluate commercial yield, and 20, to evaluate seed-rhizome yield.

Fertilization on planting consisted of $30 \mathrm{~kg} \mathrm{ha}^{-1}$ of $\mathrm{P}_{2} \mathrm{O}_{5}, 20 \mathrm{~kg} \mathrm{ha}^{-1}$ of $\mathrm{K}_{2} \mathrm{O}$, and $12 \mathrm{tha}^{-1}$ of cattle manure, while the side dressing fertilization consisted of applying $100 \mathrm{~kg} \mathrm{ha}^{-1}$ of $\mathrm{N}, 50 \%$ three months after planting and $50 \%$ a month later. During the cycle, hand hoeing and earth up were performed aiming at protecting the rhizomes against solar rays. Sprinkler irrigation was used at periods of absence of rain, with threeday irrigation shifts. Plants were driven using single stakes.

The percentage of plant emergency was evaluated from 40 to 90 days after planting (DAP), while plant height was assessed from 40 to 80 DAP, both in 10day intervals. The average mass of commercial rhizomes and the yield of commercial and seed-rhizomes were also assessed. To evaluate commercial yield, the harvest was performed nine months after planting. Rhizomes weighting between 1.5 and $2.0 \mathrm{~kg}$ were considered as commercial (Silva, 2002). Seed-rhizome yield was assessed in plants submitted to top-pruning, harvested three months after it.

Data were submitted to the variance analysis and polynomial regression, using the linear model, with $5 \%$ probability.

\section{RESULTS AND DISCUSSION}

There was significant interaction between rest periods and days after planting over emergency and plant height, as well as isolated effect of rest periods over the average mass of commercial rhizomes and yield of commercial and seed-rhizomes.

Plant emergency increased linearly 40, 50, and 60 DAP, along with the physiological rest periods, reaching maximum percentages of 45,62 , and $74 \%$, respectively, for rhizomes submitted to 100-day rest period. At 70 and 80 DAP, emergency was independent of the rest period. A decrease on emergency as the seedrhizome rest period increased was observed 90 DAP. In this date, seedrhizomes submitted to 60-day rest periods resulted in an emergency of $91 \%$, while for those submitted to $100-$ day rest periods emergency was $83 \%$ (Figure 1). The difference in emergency between these two treatments $(8 \%)$ represents less than 1.093 plant ha $^{-1}$. The low initial emergency observed for rhizomes submitted to 60-day physiological rest periods is likely to be related to their immaturity at this stage. Reduced emergency has been already observed when young rhizomes and tubers were used for propagation (Iritan 


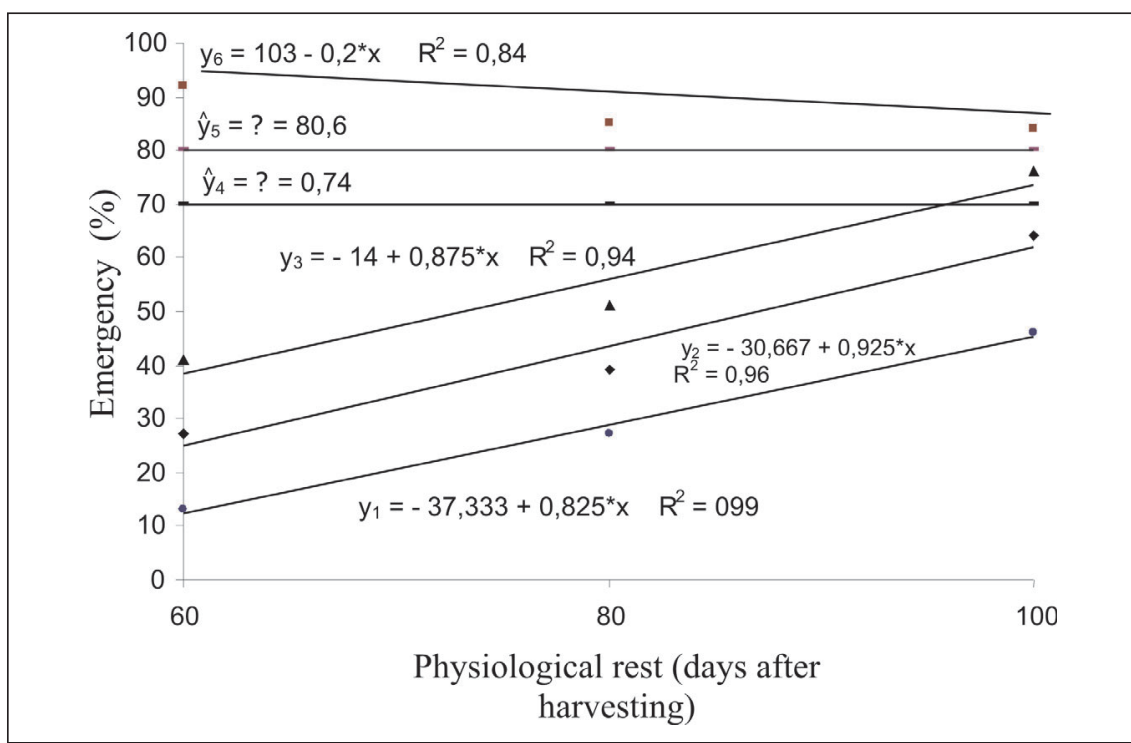

Figure 1. Emergency of yam plants $40\left(\mathrm{Y}_{1}\right), 50\left(\mathrm{Y}_{2}\right), 60\left(\mathrm{Y}_{3}\right), 70\left(\mathrm{Y}_{4}\right), 80\left(\mathrm{Y}_{5}\right)$ and $90\left(\mathrm{Y}_{6}\right)$ days after planting as affected by the rest period of seed-rhizomes (emergência de plantas de inhame $40\left(\mathrm{y}_{1}\right), 50\left(\mathrm{y}_{2}\right), 60\left(\mathrm{y}_{3}\right), 70\left(\mathrm{y}_{4}\right), 80\left(\mathrm{y}_{5}\right)$ e $90\left(\mathrm{y}_{6}\right)$ dias após o plantio, em função do período de repouso físiológico dos rizomas-sementes). Areia, UFPB, 2006.

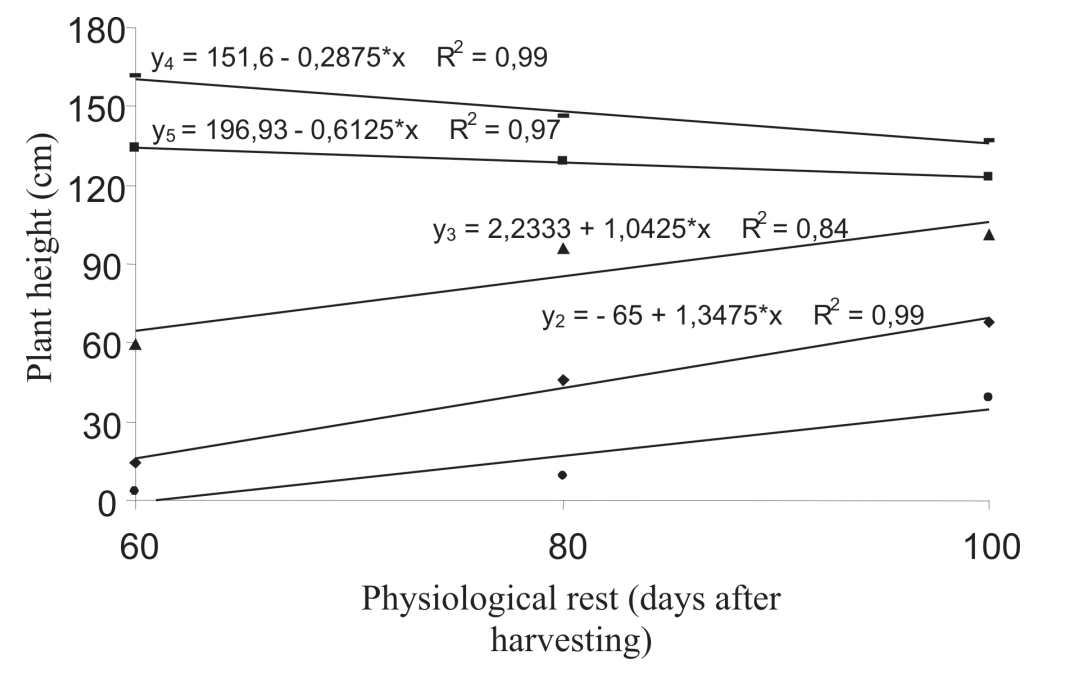

Figure 2. Height of yam plants $40\left(\mathrm{Y}_{1}\right), 50\left(\mathrm{Y}_{2}\right), 60\left(\mathrm{Y}_{3}\right), 70\left(\mathrm{Y}_{4}\right), 80\left(\mathrm{Y}_{5}\right)$, and $90\left(\mathrm{Y}_{6}\right)$ days after planting, as affected by the rest period of seed-rhizomes (altura de plantas de inhame $40\left(\mathrm{y}_{1}\right), 50\left(\mathrm{y}_{2}\right), 60\left(\mathrm{y}_{3}\right), 70\left(\mathrm{y}_{4}\right)$ e $80\left(\mathrm{y}_{5}\right)$ dias após o plantio, em função do período de repouso fisiológico dos rizomas-sementes). Areia, UFPB, 2006.

$\&$ Thorton, 1984). The decrease in emergency observed 90 DAP associated with the use of seed-rhizomes that rested for 100 days is probably due to their physiological aging, caused by the consumption of their reserves during the resting period. The use of physiologically old tubers in potato results in smaller vigor and reduced stands (Finger \& Fontes, 1999). In potato, Raouf (1979) and Rezende (2007) observed a decrease on plant final stand at field due to the 100-day rest. On the other hand, heights observed 70 and 80 DAP reduced as the physiological rest period of the seedrhizome increased, with the tallest plants coming out from seed-rhizomes with 60-day rest (Figure 2). The reduction in plant height assessed 70 and 80 days for seed-rhizomes exposed to a rest period of 100 days can be assigned to the high losses of reserves in these rhizomes before planting. According to Santos (1996), yam seed-rhizomes with more than 90 days of rest can present a vigorous initial plant growth, but without correspondence on further plant development.

Each additional day in the physiological rest period induced decreases of $12.4 \mathrm{~g}$ in the average mass of commercial rhizomes and 135 and 95 $\mathrm{kg} \mathrm{ha}^{-1}$ respectively in commercial and seed rhizome yields. When seedrhizomes with 60-day rest were used for planting, the average mass and the yield of commercial rhizomes were respectively $1.22 \mathrm{~kg}$ and $13.1 \mathrm{t} \mathrm{ha}^{-1}$, with the yield of seed-rhizomes reaching 7.7 $\mathrm{t} \mathrm{ha}^{-1}$. For seed-rhizomes with a 100-day rest period, the average mass of commercial rhizomes was $0.73 \mathrm{~kg}$ and commercial and seed-rhizome yields were, respectively, 7.7 and $1.7 \mathrm{t} \mathrm{ha}^{-1}$ (Figures 1 and 2). In the same way that seed-rhizomes with long physiological rest periods reduced plant emergency, there was also a decrease in yield (Santos, 1996). In potato, Bohl et al. (2003) and Pavlista (2004) reported that as seed-potatoes grown physiologically old, yield is significantly compromised due to the high losses of tuber reserves. Rezende (2007) observed that the longer the seed-potato storage period in room temperature was, the smaller total and commercial yields were.

The yield of commercial rhizomes achieved by planting seed-rhizomes with 60-day rest exceeded in 10 ton ha${ }^{1}$ the average found by Santos (1996) for the State of Paraíba. This result indicates the potential impact of anticipating planting on production, taking into account that farmers usually use seedrhizomes with about 90 days of physiological rest (Santos, 1998). Considering that the post-harvest period of yam seed-rhizomes can influence 
yield, the planting of this species should be carried out 60 days after harvesting. Seed-rhizomes with a post-harvest period longer than 80 days should not be used for planting.

\section{ACKNOWLEDGEMENTS}

Authors thank CNPq (The National Council for Scientific and Technological Development) for the financial support. Ademar P de Oliveira holds a CNPq grant in Productivity in Research; Francisco de Assis P Leonardo and Iordam da S Cruz hold scholarships for respectively Scientific Initiation and Technical Support.

\section{REFERENCES}

ARAÚJO FC. 1982. Aspectos sobre o cultivo do cará-da-costa. Recife: Assessoria de Fruticultura. 33 p. (Boletim Técnico 29).

BEUKEMA HP; VAN DER ZAAG DE. 1979. Potato improvement: some factors and facts. Wageningen: the International Agricultural Center. 224 p.

BISOGNIN DA; CENTENARO R; MISSIO EL. 1998. Uso do ácido giberélico na quebra de dormência e de dominância apical em batata. Ciência Rural 28: 205-213.

BOHL WH; OLSEN N; LOVE SL, NOLTE P. 2003. Potato seed management: seed size and age. Idaho: Agricultural Experiment Station. p. 91-114 (CIS 1031).

EMBRAPA - EMPRESA BRASILEIRA DE PESQUISAAGROPECUÁRIA. 1999. Sistema Brasileiro de Classificação de Solos. Brasília: Embrapa Produção de Informações. 412 p.

FERNANDEZ ML. 1988. Los regladores del crescimiento en el cultivo de la papa. Havana: INCA. 22 p.

FINGER FL; FONTES PCR. 1999. Manejo póscolheita da batata. Informe Agropecuário 20: $105-111$.

FINGER FL; FONTES PCR; PUIATTI M. 2005. Dormência e tuberização. In: FONTES PCR (Ed). Olericultura: teoria e prática. Viçosa: UFV. p. 31-38.

IRITANI WM; THORNTON RE. 1984. Potatoes: influencing seed tuber behavior. Pacific North West: $16 \mathrm{p}$.

OLIVEIRA AP; FREITAS NETO PA; SANTOS ES. 2002. Qualidade do inhame 'Da Costa' em função das épocas de colheita e da adubação orgânica. Horticultura Brasileira 20: 225-118.

PAVLISTAAD. 2004. Physiological aging of seed tubers. Nebraska Potatoes Eyes 16: 43.

RAOUF GSM. 1979. Effects of physiological age of seed tubers in the early potato variety. Abeystwyth: University College of Wales. 33p. (M.Sc. thesis).

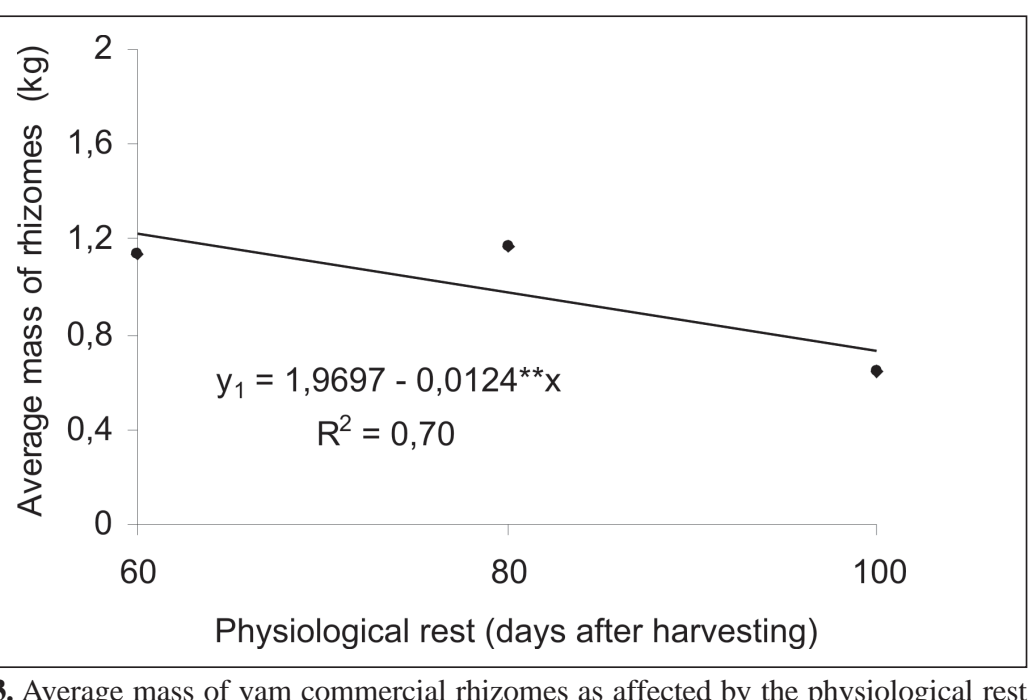

Figure 3. Average mass of yam commercial rhizomes as affected by the physiological rest periods of seed-rhizomes (massa média de rizomas comerciais de inhame em função do período de repouso fisiológico de rizomas-semente). Areia, PB, 2006.

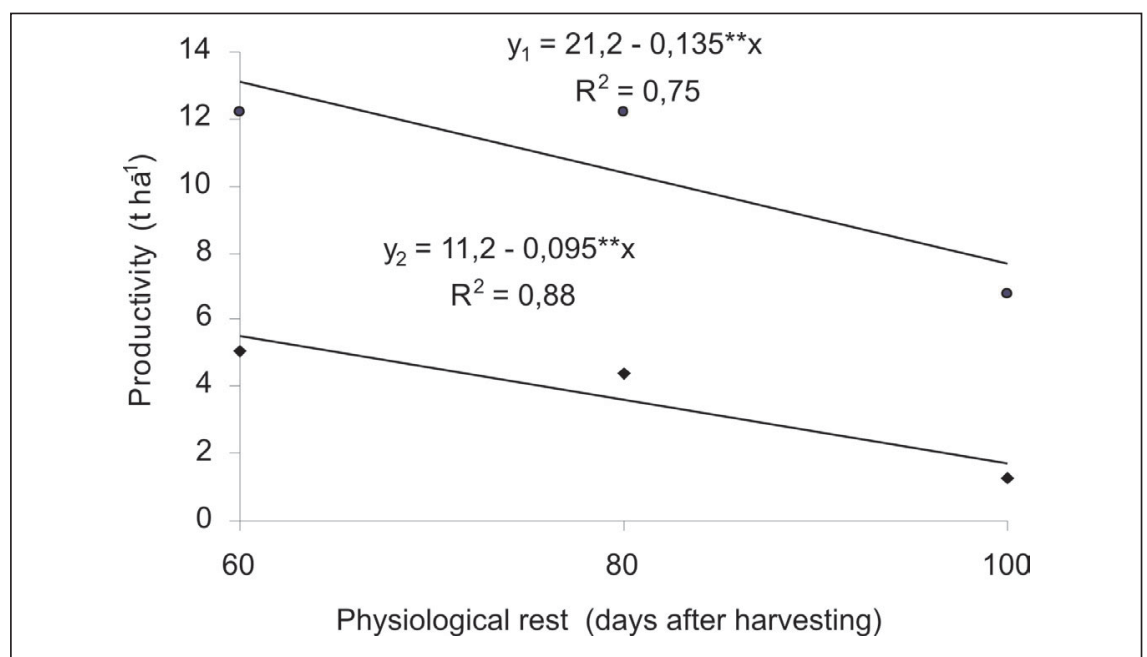

Figure 4. Yam commercial rhizomes $\left(\mathrm{Y}_{1}\right)$ and seed-rhizomes $\left(\mathrm{Y}_{2}\right)$ yield as affected by the physiological rest periods of seed-rhizomes (Produção de rizomas comerciais $\left(\mathrm{y}_{1}\right)$ e de rizomas-semente $\left(\mathrm{y}_{2}\right)$ de inhame em função do período de repouso fisiológico de rizomasemente). Areia, UFPB, 2006.

REZENDE RLG. 2007. Efeito da idade fisiológica da batata-semente sobre características produtivas da batata (Solanum tuberosum $L$.) cv. Atlantic. Campinas: IAC. $43 \mathrm{p}$ (Tese mestrado).

SANTOS ES. 1996. Inhame (Dioscorea spp.): aspectos básicos da cultura. João Pessoa: EMEPA-PB/SEBRAE, 158 p.

SANTOS ES. 1998. Sistemas de plantio e tamanhos de rizóforos-semente de inhame. In: CONTRIBUIÇÃO TECNOLÓGICA PARA A CULTURA DO INHAME NO ESTADO DA PARAÍBA. João Pessoa: EMEPA-PB. p. 27-35.
SANTOS ES; MACÊDO LS. 2002. Tendências e perspectiva da cultura do inhame (Dioscorea sp) no Nordeste do Brasil. In: SIMPÓSIO NACIONAL SOBRE AS CULTURAS DE INHAME E TARO, 2. Anais... João Pessoa: EMEPA-PB. p. 19-32.

SILVA AA. 1971. Cultura do cará-da-costa. Fortaleza: Banco do Nordeste do Brasil. 65 p.

SILVADA. 2002. Novas opções tecnológicas para o cultivo do inhame (Dioscorea $\mathrm{sp}$ ) no nordeste do Brasil. In: SIMPÓSIO NACIONAL SOBRE AS CULTURAS DE INHAME E TARO, 2. Anais... João Pessoa: EMEPA-PB. p. $80-81$.

SOUZA ZS. 2003. Ecofisiologia. In: PEREIRA AS; DANIELS J. (Ed). O cultivo da batata na região sul do Brasil. Brasília: Embrapa Informação Tecnológica. p. 80-104. 